\title{
Dekontaminacija površina u bolničkoj sredini vodikovim peroksidom - naša iskustva $u$ KB Dubrava
}

1 Dubravka Grgurić

1 Valentina Košćak

1 Klinička bolnica Dubrava, Zagreb

\section{Sažetak}

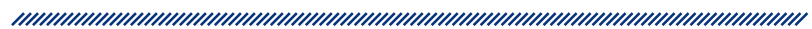

Sposobnost bakterija da prežive na različitim površinama u bolničkoj sredini važan je čimbenik njihova prijenosa s bolesnika ili zdravstvenog djelatnika u okolinu te na drugu osobu ili bolesnika. Iz navedenih su razloga temeljito čišćenje i dezinfekcija okoline vrlo važni, budući da kontaminirana okolina može služiti kao rezervoar potencijalnih patogena. Dezinfekcija se može provoditi mehanički (ručno) ili aparatom. KB Dubrava posjeduje aparat za dekontaminaciju, Glosair ${ }^{\top \mathrm{M}} 400$, koji u prostor raspršuje vodikov peroksid te u određenom kontaktnom vremenu provodi dekontaminaciju prostora i površina.

Dekontaminacija prostora aparatom provodi se nakon prekida mjera izolacije u bolesničkim sobama, tj. nakon otpusta bolesnika kod kojeg je izoliran višestruko otporni mikroorganizam. Također se prema indikaciji provodi dekontaminacija operacijske sale i prostora tj. bolesničke sobe nakon provođenja zaštitne izolacije te kod provođenja protuepidemijskih mjera u slučaju pojave bolničkih epidemija. Tijekom aktivne faze dezinfekcije aparat ispušta vodikov peroksid te u prostoru stvara maglicu koja dezinficira svu opremu i prostor. Jedan ciklus dekontaminacije traje tri sata. Nakon de- zinfekcije prostor je siguran za ulazak novog bolesnika i osoblja.

Prednosti su dekontaminacije površina u bolničkoj sredini aparatom koji raspršuje vodikov peroksid neoštećivanje medicinskog pribora i opreme: ne ostavlja rezidue, stoga se može dezinficirati i visokosofisticirana oprema. Provedena kontrola učinkovitosti vodikova peroksida na površinama pokazuje veliku djelotvornost. Sve su površine sterilne u usporedbi s analiziranim nalazima obrisaka površina nakon mehaničkog čišćenja, gdje sporadično zaostaje manji broj patogena. Provođenje procesa dekontaminacije prostora aparatom pokazalo se učinkovitim u kontroli i prevenciji bolničkih infekcija.

Ključne riječi: dezinfekcija, patogeni mikroorganizam, bolnička okolina

Datum primitka: 12.04.2017.

Datum prihvaćanja: 01.06.2017.

DOI: $10.24141 / 3 / 1 / 11$

Adresa za dopisivanje:

Dubravka Grgurić

Klinička bolnica Dubrava

Avenija Gojka Šuška 6, 10000 Zagreb

E-pošta: dgrguric@kbd.hr

Tel.: +38512902444 


\section{Uvod}

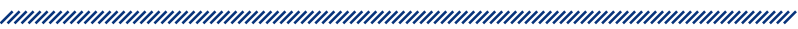

Svakodnevni napredak medicine omogućio je pružanje kvalitetne zdravstvene skrbi i produženje životnog vijeka, a sve veća upotreba antibiotika dovela je do pojave multirezistentnih mikroorganizama (MRMO), kao i njihova širenja u bolničkoj sredini, gdje dovode do pojave infekcija povezanih s bolničkom skrbi.

Bolnička infekcija (infekcija povezana sa zdravstvenom skrbi) jest svaka infekcija bolesnika koja se javlja neovisno o primarnom oboljenju ili svaka infekcija zdrave osobe za koju se utvrdi da nastala kao posljedica dijagnostike, liječenja ili skrbi, a razvije se tijekom liječenja i skrbi, nakon dijagnostičkog ili terapijskog postupaka i otpusta iz bolnice odnosno ustanove koja pruža usluge socijalne skrbi u određenom periodu. ${ }^{1}$

O kolonizaciji bolesnika govorimo kada je prisutan mikroorganizam na mjestu/mjestima na tijelu bez prisutnosti simptoma ili kliničke manifestacije bolesti ili infekcije. Važno je napomenuti da kolonizacija može dovesti do razvoja infekcije.

Kolonizacija hospitaliziranih bolesnika ovisi o: trajanju hospitalizacije i učestalosti hospitalizacije, težini osnovne bolesti (imunokompromitirani bolesnici, komorbiditeti), prisutnosti kroničnih rana (ulkusi, dekubitusi), prisutnosti invazivnih pomagala, nedavnoj ili ponovljenoj primjeni antibiotika (razvoj rezistencije bakterija) te o stanju uhranjenosti bolesnika.

Čimbenici koji povezuju pojave kontaminacije, kolonizacije i infekcije patogenim mikroorganizmima mogu se podijeliti u tri osnovne grupe:

a) jatrogeni i oni povezani sa zdravstvenom njegom (prisutnost mikroorganizama na rukama zdravstvenog osoblja, na površinama koje nisu dobro očišćene, kod invazivnih postupaka)

b) organizacijski (omjer medicinskih sestara prema broju bolesnika, fizički raspored radnih prostorija i bolesničkih kreveta)

c) povezani $s$ bolesnikom (imunokompromitiranost, dužina boravka u bolnici). ${ }^{2,3}$

\section{Okolina bolesnika i MRMO}

Svaka osoba dnevno odbaci više od milijun mrtvih stanica i otprilike $10 \%$ njih nosi 1 do 5000 živih bakterija prisutnih kao mikrokolonije. Okolina u zdravstvenim ustanovama konstantno je kontaminirana mikroorganizmima inficiranih/koloniziranih bolesnika, osoblja i posjetitelja. ${ }^{4}$

Kontakt je najčešći način prijenosa infekcija povezanih sa zdravstvenom skrbi. ${ }^{4}$ Razlikujemo direktni kontakt (fizički kontakt s bolesnikom) i indirektni kontakt preko kontaminiranog posrednog objekta (stvari i oprema) ili osobe.

Na broj i tipove mikroorganizama utječe broj osoba u okolini, količina aktivnosti, količina vlage, prisutnost materijala koji omogućavaju rast mikroorganizama, brzina kojom se uklanjaju mikroorganizmi suspendirani u zraku te tip površine i njezina orijentacija (horizontalna ili vertikalna). Smatra se da površine koje su u neposrednoj blizini bolesnika te su često dodirivane rukama djelatnika predstavljaju povećan rizik za bolesnika, ${ }^{5,6}$ mogu biti kontaminirane bolničkim sojevima bakterija koje se putem ruku osoblja prenesu u neposrednu blizinu bolesnika, a potom i na bolesnika. Višestruko otporni mikroorganizmi koji uzrokuju bolničke infekcije imaju sposobnost da dugo prežive na površinama u bolničkom okruženju. Najčešće su spominjani meticilin-rezistentni Staphylococcus aureus (MRSA), beta-laktamaze proširenog spektra (ESBL sojevi), multirezistentni Acinetobacter baumannii, Clostridium difficile, vankomicin-rezistentni enterokok (VRE) i norovirus. ${ }^{7,8}$ Velik problem u kontroli bolničkih infekcija uzrokovanih VRE-om je što dugo preživljava u bolničkom okruženju i otporan je na standardne metode čišćenja. ${ }^{7}$ MR Acinetobacter baumannii dugo opstaje u bolničkom okruženju, i do pet mjeseci. Često se može naći na površinama koje su u neposrednoj blizini bolesnika, osobito kod bolesnika koji su kolonizirani. Važnu ulogu u kontroli bolničkih epidemija uzrokovanih MR-om Acinetobacter baumannii imaju visoki standardi čišćenja bolničkih površina. ${ }^{9}$ Također MRSA pozitivan pacijent kontaminira svojim sojem površine koje su u neposrednoj blizini. Zdravstveno osoblje koje uđe u sobu gdje se nalazi bolesnik s izoliranim MRSA-om (te odmah po izlasku ne skine rukavice, pregaču i ne dezinficira ruke) dokazano će prenijeti pacijentov soj na rukavicama ili pregači na druge bolesnike. ${ }^{10}$ 
Sposobnost bakterija da prežive na različitim površinama u bolničkoj sredini važan je čimbenik za njihov prijenos s pacijenta ili zdravstvenog djelatnika u okolinu, a zatim i na drugu osobu. Da bi se djelotvorno utjecalo na smanjenje pojave i kontrolu multirezistentnih mikroorganizama, uz aktivno praćenje infekcije i prepoznavanje tipova rezistencije na antibiotike, važno je provoditi mjere izolacije bolesnika u zasebnu sobu te primjenjivati standardne mjere zaštite za sve bolesnike. Cilj je prevencija širenja patogenih mikroorganizama na druge bolesnike i okolinu te pravilno provođenje dezinfekcije i sterilizacije pribora i medicinske opreme. Planirano i kontinuirano provođenje edukacije osoblja i bolesnika jednako je važan faktor u prevencije širenja infekcija povezanih s bolničkom skrbi.

Prijenos mikroorganizama s bolesnika na površine u okolini odvija se putem kontakata kontaminiranih ruku, ako se ne provodi pravilna higijena ruku i/ ili putem kontakata bolesnika s njegovom okolinom, ako nije bila adekvatno očišćena i dezinficirana. Važno je pravilno provoditi higijenu ruku bilo utrljavanjem alkoholnog antiseptika bilo pranjem ruku tekućim sapunom i vodom, a pri tome je važno pridržavanje koncepta Mojih pet trenutaka za higijenu ruku prema naputku Svjetske zdravstvene organizacije te Smjernica za higijenu ruku u zdravstvenim ustanovama. ${ }^{11}$

Indikacije su za higijenu ruku:

1. prije kontakta s bolesnikom odnosno njegovom okolinom

2. prije aseptičkog postupka

3. nakon izlaganja riziku od kontaminacije tjelesnim tekućinama i izlučevinama bolesnika

4. nakon kontakta s bolesnikom

5. nakon kontakta s bolesnikovom okolinom ako $\mathrm{i}$ nije bilo kontakta s bolesnikom.

Djelotvorno čišćenje okoline važno je jer kontaminirana okolina može biti rezervoar potencijalnih patogena. Nakon čišćenja slijedi dezinfekcija površina. Primjenjuju se dezinficijensi primjerenog stupnja djelotvornosti, ovisno o površinama koje se dezinficiraju. Prema namjeni razlikujemo dezinficijense niskog, srednjeg i visokog stupnja djelotvornosti. Ako imamo dokazanu bolničku infekciju ili kolonizaciju MRMO-om, za dezinfekciju površina upotrebljavamo dezinficijens visokog stupnja djelotvornosti. Jedan je od predstavnika dezinficijensa visokog stupnja djelotvornosti i vodikov peroksid.

Prostori bolničkog okruženja s obzirom na rizik od prenošenja infekcija dijele se na:
- prostore visokog rizika (jedinice intenzivnog liječenja, operacijske sale)

- prostore srednjeg rizika (bolesničke sobe, kirurški odjeli)

- prostori niskog rizika (čekaonice i hodnici).

Okolina ima važnu ulogu u prijenosu bolničkih infekcija. Postoji rizik za akviriranje mikroorganizama iz okoline ako ona nije adekvatno očišćena i dezinficirana. Bolesnici primljeni u bolesničku sobu u kojoj je boravio bolesnik s MRMO-om pod rizikom su da akviriraju patogen iz okoline te mogu biti kolonizirani ili inficirani istim patogenom.

\section{Praćenje „kretanja" MRMO-a putem izolata u KB Dubrava}

U KB-u Dubrava svakodnevno se prate bolnički izolati MRMO-a: Staphylococcus aureus MRSA, beta-laktamaze proširenog spektra (ESBL sojevi), MR Acinetobacter baumannii, Clostridium difficile, vankomicin-rezistentni enterokok (VRE) i bilježe se u sustav tablice. Uzimaju se nadzorne kulture za bolesnike primljene u JIL i za bolesnike premještene iz druge zdravstvene ustanove ili iz domova za stare i nemoćne.

Razlikujemo izolate koji su „stečeni” u KBD-u, zatim izolate koji su detektirani kod bolesnika koji su bili premješteni iz drugih suradnih ustanova, domova za stare i nemoćne ili su došli od kuće te na kraju prikazani izolati za koje se ne može sa sigurnošću utvrditi jesu li bolesnici došli ili stekli MRMO u KBD-u (slika 1).

Kad se usporede rezultati praćenja od 2012. do 2015. godine, vidljivo je da je Staphylococcus aureus MRSA u stalnom opadanju, osobito izolati koji su „stečeni” u KBD-u. Zamijećen je porast izolata u bolesnika koji dolaze iz drugih ustanova, domova za stare i nemoćne, koji imaju pridružene brojne komorbiditete često udružene s imunokompromitiranošću te su kao takvi skloni akviziciji MRMO-a iz okoline, što često dovodi do kolonizacije bolesnika, a posljedično i do infekcije. 


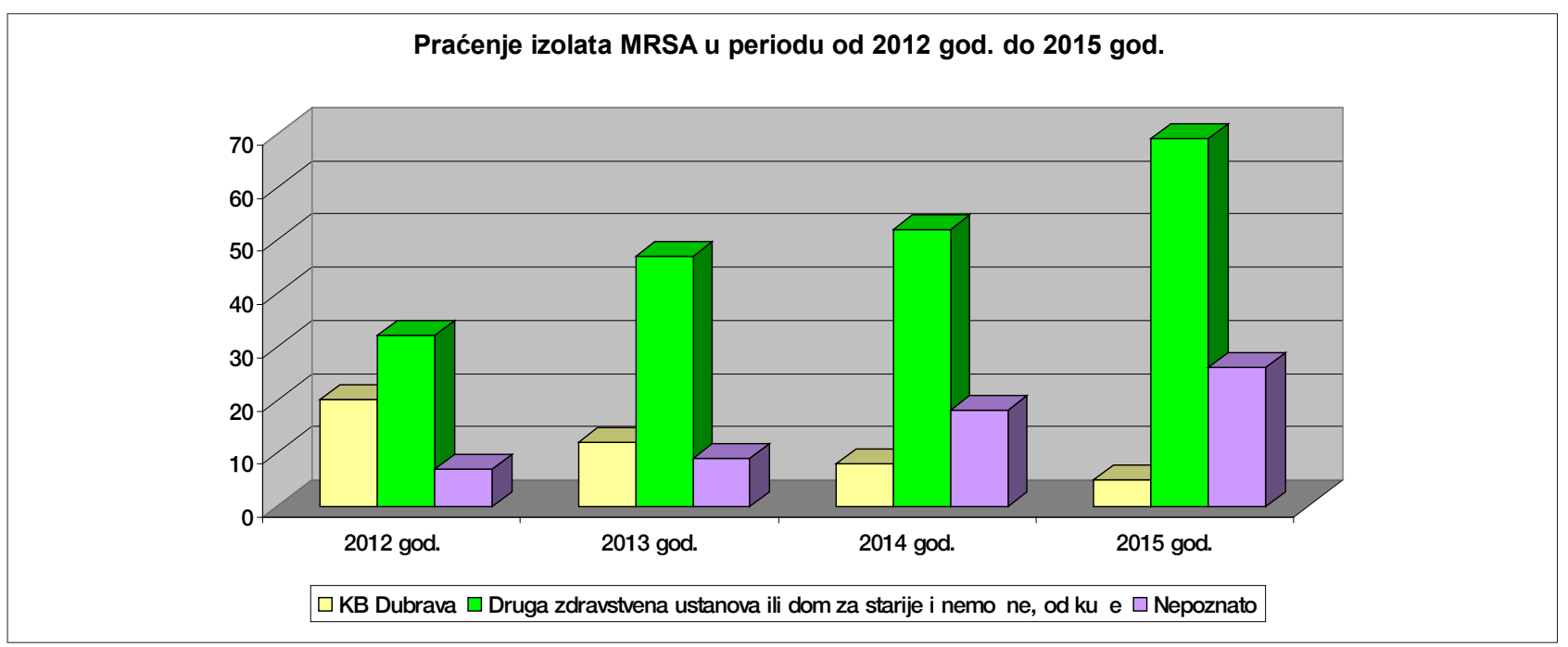

Slika 1. Prikaz praćenja izolata MRMO-a Staphylococcus aureus MRSA u periodu od 2012. do 2015. godine.

\section{Naše iskustvo u primjeni nove metode dezinfekcije bolničkog prostora vodikovim peroksidom}

Dekontaminacija prostora aparatom provodi se nakon prekida mjera izolacije u bolesničkim sobama nakon otpusta bolesnika kod kojeg je izoliran MRMO. Također se prema indikaciji provodi dekontaminacija operacijske sale, prostora (bolesničke sobe) nakon provođenja zaštitne izolacije te kod provođenja protuepidemijskih mjera u slučaju pojave bolničkih epidemija. Posebice se preporučuje kod pojave infekcija uzrokovanih rezistentnim mikroorganizmima kao što su MR Acinetobacter baumannii, Staphylococcus aureus MRSA, beta-laktamaze proširenog spektra (ESBL sojevi) i Enterococcus faecium VRE te kod proljeva uzrokovanog sporama Clostridium difficile.

Vodikov peroksid pokazao se vrlo učinkovitim u dekontaminaciji bolničkih prostora. Tijekom tri sata svojeg djelovanja dopire do svih površina, i onih teže dostupnih, uništavajući i reducirajući broj mikroorganizama. ${ }^{12-16}$ Tijekom aktivne faze dekontaminacije aparat ispušta maglicu koja se sastoji od 5 do $6 \%$ vodikova peroksida $\left(\mathrm{H}_{2} \mathrm{O}_{2}\right), 50$ ppm srebra (Ag) i $95 \%$ deionizirane vode. Vodikov peroksid $\left(\mathrm{H}_{2} \mathrm{O}_{2}\right)$ ima oksidirajuće svojstvo koje uništava mikroorganizme putem hidroksil slobodnih radikala, a kationi srebra $(\mathrm{Ag})$ inaktiviraju mikroorganizme putem inhibicije sinteze proteina. ${ }^{17}$
Aparat omogućuje dekontaminaciju medicinskog pribora, prostora i opreme; veličina prostora koja se može dezinficirati kreće se od $10 \mathrm{~m}^{3}$ do $200 \mathrm{~m}^{3}$. Tijekom aktivne faze dezinfekcije aparat ispušta vodikov peroksid te se u prostoru stvara maglica kojom se dezinficira sva oprema i prostor. Jedan ciklus dekontaminacije traje tri sata. Nakon dezinfekcije prostor je siguran za ulazak novog bolesnika. Odluku o potrebi za dezinfekcijom prostora aparatom donosi Povjerenstvo za bolničke infekcije KB-a Dubrava.

U KB-u Dubrava u svibnju 2011. godine prvi se put nabavlja aparat za dekontaminaciju prostora te se počinje provoditi dezinfekcija prostora. Zbog povećanih potreba i iznimne važnosti u prevenciji bolničkih infekcija, KB Dubrava u 2014. godini nabavlja još jedan aparat koji se upotrebljava u operacijskim salama.

\subsection{Učinkovitost dekontaminacije vodikovim peroksidom}

Godine 2014. uzeti su obrisci s neživih površina u prostorima izolacije nakon otpusta bolesnika kako bi se ispitala učinkovitost dekontaminacije vodikovim peroksidom. Obrisci su uzeti prije mehaničkog čišćenja, nakon mehaničkog čišćenja te nakon dekontaminacije prostora izolacije vodikovim peroksidom. Tablica 1 prikazuje oduzimanje obrisaka s površina u prostoru izolacije nakon otpusta bolesnika kod kojeg je izoliran uzročnik Acinetobacter baumannii. Obrisci su uzimani u prostoru izolacije i nakon bolesnika kod kojeg je izoliran Enterobacter cloacae ESBL te bolesnika s izolatom Staphylococcus aureus MRSA. 
Tablica 1. Uzimanje obrisaka s površina u prostoru izolacije nakon otpusta bolesnika kod kojeg je izoliran uzročnik Acinetobacter baumannii

\begin{tabular}{|c|c|c|c|}
\hline $\begin{array}{l}\text { ODUZIMLANJE } \\
\text { UZORAKA }\end{array}$ & $\begin{array}{l}\text { PRIJE MEHANICKOG } \\
\text { CISCENJA }\end{array}$ & $\begin{array}{l}\text { NAKON MEHANICKOOG } \\
\text { CISCENJA }\end{array}$ & $\begin{array}{l}\text { NAKON } \\
\text { DEZINFEKCIJE } \\
\text { GLOSALR-OM }\end{array}$ \\
\hline OBRISAK ormaruca & Acutetobacter baumannzt (veliki broj) & Actinetabacter basmonurivirlo mali broj) & atrrilino \\
\hline OERISAK KREVETA 1 & Acintobacter baumathiti (mali broj) & 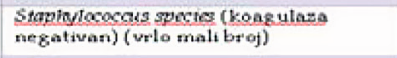 & sterilno \\
\hline OBRISAK TRAPEZA & Acintetobacter bulumaini (vrlo mali broj) & Actinedaceer bas mant (vrlo mali broj) & sterilno \\
\hline OERISAK STOLA & Actietobacter baunaninif (weliki broj) & steritno & sterilino \\
\hline OERISAK AKEIMMANA & Acitetobaster batumoninit (vrlo mali broj) & aterilno & strrilino \\
\hline OBRASAK PODA & 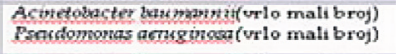 & ateritno & oterilno \\
\hline OERISAK RADIJATORA & 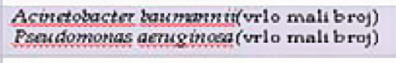 & aterilno & sterilino \\
\hline OBRSAK KVAKE & Acurctobacter kaumannit (velth.t broj) & oterilino & iterilno \\
\hline $\begin{array}{l}\text { OBRISAK GARDEROBNI } \\
\text { ORMARIC }\end{array}$ & Acinetoluater haumennii (veliki broy) & sterilno & sterilno \\
\hline OERISAK KREVET 2 & Acotetobacter baumanitit (urlo mali brof) & Actidebacter bas monnti (orlo mali brof) & oteriline \\
\hline
\end{tabular}

Provedena kontrola učinkovitosti vodikova peroksida na površine pokazuje veliku djelotvornost. Sve su površine sterilne u usporedbi s analiziranim nalazima obrisaka površina nakon mehaničkog čišćenja, gdje sporadično zaostaje manji broj patogena.

\subsection{Postupak pripreme sobe za dekontaminaciju}

Mehaničko čišćenje sobe provodi se po standardnom protokolu naše ustanove. Iz sobe se ukloni prljavo rublje, otpad, sav materijal od papira, celuloze i tkanine te otvorene boce s tekućinom. Mehanički se peru površine: zid, strop, pod, bolesnički krevet, bolesnički ormarić, stol i sve horizontalne površine te pripadajući sanitarni čvor. Ostave se otvorena vrata ormara, bolesničkog ormarića i ladice, kako bi sve površine bile potpuno suhe i dostupne dezinfekciji.

\subsection{Proces dekontaminacije prostora}

Kada su sve površine u prostoru suhe, slijedi dekontaminacija prostora aparatom.

Priprema sobe: zatvore se prozori i pomoćna vrata, isključen je klimatizacijski uređaj i požarni alarm (kontrolni centar isključuje vatrodojavu i klimatizaciju), PVC vrećama i ljepljivim trakama prekriju se otvori ventilacije i sustav uzimanja zraka, izmjeri se površina sobe, izračuna volumen prostora. Aparat se smjesti u kut sobe, što omogućuje slobodno ispuštanje pare po dijagonali na 1,5 m. Trakama se zalijepe vrata i ključanica, tako da se spriječi širenje vodikova peroksida kroz rubove. So- ba se označi natpisom „Ne ulazi! Dezinfekcija u tijeku.” i napiše se točno vrijeme trajanja ciklusa. Na zaslonu daljinskog upravljača provjeri se je li završio proces dekontaminacije u predviđenom vremenu. Kada prijenosni senzor za vodikov peroksid pokaže odsutnost vodikova peroksida u sobi, tada se ulazi u sobu i završava proces dekontaminacije. Kad je dekontaminacija završena, uključuje se klimatizacijski uređaj i vatrodojava (kontrolni centar).

\begin{tabular}{|c|c|}
\hline Godina & Broj dezinfekcija \\
\hline početak svibnja 2011. & 114 \\
\hline 2012. & 197 \\
\hline 2013. & 268 \\
\hline 2014. & 417 \\
\hline 2015. & 504 \\
\hline
\end{tabular}

U tablici 2 vidljivo je da je na godišnjoj razini došlo do porasta broja dezinfekcija, što je povezano i s brojem izoliranih MRMO-a (pojačano je praćenje i uzimanje nadzornih kultura), a i bilo je potrebno određeno vrijeme da djelatnici prihvate potrebu dezinfekcije prostora kao nešto što se redovito obavlja prema Protokolu čišćenja i dezinfekcije.

Dezinficirali su se prostori nakon odlaska bolesnika iz prostora izolacije kod kojih je bila prisutna kolonizacija 
ili infekcija MRMO-om te operacijske sale nakon operativnih zahvata bolesnika kod koji je izoliran MRMO. Budući da proces dekontaminacije prostora traje tri sata, dnevno je moguće odraditi najviše tri do četiri dekontaminacije. U 2014. godini KBD nabavlja još jedan aparat te je vidljiv porast broja dezinfekcija. Ako je potrebno, moguće je istodobno dezinficirati dva prostora. Provođenje procesa dekontaminacije prostora aparatom pokazalo se učinkovitim u kontroli i prevenciji bolničkih infekcija.

\section{Zaključak}

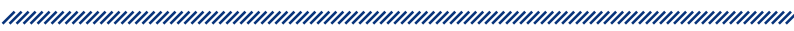

Jedan od najčešćih načina prijenosa bolničkih infekcija zbiva se preko kontaminiranih ruku zdravstvenih djelatnika; putem direktnog ili indirektnog kontakta.

U prijenosu patogenih mikroorganizama važnu ulogu imaju kontaminirane površine jer na površinama u bolničkoj okolini patogeni mikroorganizmi mogu preživjeti duže vrijeme. Razlikujemo dvije vrste površina: one s kojima ruke minimalno dolaze u kontakt (podovi, zidovi, stropovi) i one s kojima ruke često dolaze u kontakt (bolesnički krevet, bolesnički ormarić, kvake na vratima...).

Mehanička (ručna) dezinfekcija nije uvijek dovoljna u kontroli širenja bolničkih infekcija. Ispitivanjem učinkovitosti dezinfekcije aparatom Glosair ${ }^{\top \mathrm{M}} 400$, nalazi ukazuju na zadržavanje patogenih mikroorganizama u manjem broju na pojedinim površinama nakon mehaničkog čišćenja, dok su nakon dezinfekcije aparatom nalazi obrisaka površina sterilni. Učinkovitost mehaničke dezinfekcije ovisi o ljudskom faktoru, pravilnom odabiru dezinficijensa i njegovoj pravilnoj distribuciji po svim površinama u određenom kontaktnom vremenu. Dezinfekcija aparatom osigurava dezinfekciju površina koje se često zanemaruju kao što su utičnice, prekidači, radijatori, kvake na vratima te teško dostupna mjesta. Prednosti su dekontaminacije površina u bolničkoj sredini aparatom koji raspršuje vodikov peroksid da ne oštećuje medicinski pribor i opremu te ne ostavlja rezidue, stoga se može dezinficirati i visokosofisticirana oprema. Nakon završenog procesa dezinfekcije prostor je siguran za ulazak novog bolesnika i osoblja. Sigurnost bolesnika imperativ je kvalitetne zdravstvene zaštite.

Uz svakodnevno provođenje higijene ruku i pridržavanje preporuka Mojih pet trenutaka SZO-a te preporuka asep- tičke tehnike rada, važno je temeljito mehaničko čišćenje i dezinfekcija bolničke okoline, osobito okoline u neposrednoj blizini bolesnika. Potreban je dobar program unaprjeđenja higijene okoline te kontinuirana edukacija i trening osoba koje sudjeluju u provođenju higijene, kao i osoba koje sudjeluju u kontroli i nadzoru. Dobri programi nadzora i kontrole smanjuju pojavnost bolničkih infekcija, smanjuju smrtnost, duljinu boravka bolesnika u bolnici te troškove povezane s hospitalizacijom. 


\section{Literatura}

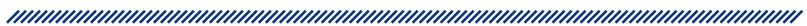

1. Ministarstvo zdravlja. Pravilnik o uvjetima i načinu obavljanja mjera za sprečavanje i suzbijanje bolničkih infekcija. Narodne novine 85/2012.

2. Šarić M, Buljubašić A, Žunić LJ, et al. Mjere za sprečavanje i suzbijanje širenja bolničkih infekcija s osvrtom na pravnu regulativu u Republici Hrvatskoj. Hrvatski časopis za javno zdravstvo [internet]. 2013; 9:(35): 158-175. Dostupno na: https://hcjz.hr/index.php/hcjz/issue/view/15 (pristupljeno 4. svibnja 2017.).

3. Gordts B. Models for organisation of hospital infection control and prevention programmes. Clin Microbiol Infect. 2005; 11: 19-23.

4. Damani N. Priručnik o prevenciji i kontroli infekcija. Prijevod trećeg izdanja. Zagreb: Medicinska naklada; 2015.

5. Bhalla A, Pultz NJ, Gries DM, et al. Acquisition of nosocomial pathogens on hands after contact with environmental surfaces near hospitalized patients. Infect Control Hosp Epidemiol. 2004; 25: 164-167.

6. Dancer SJ. The role of environmental cleaning in the control of hospital-acquired infection. J Hosp Infect. 2009; 73: 378-385.

7. Dancer SJ. Mopping up hospital infection. J Hosp Infect. 1999; 43: 85-100.

8. Dancer SJ. Importance of the environment in meticillinresistant Staphylococcus aureus acquisition: the case for hospital cleaning. Lancet Infect Dis. 2008; 8: 101-113.

9. Denton M, Wilcox MH, Parnell P, et al. Role of environmental cleaning in controlling an outbreak of Acinetobaccter baumannii on a neurosurgical intensive care unit. J Hosp Infect. 2004; 56: 106-110.
10. Boyce JM, Potter-Bynoe G, Chenevert C, King T. Environmental contamination due to methicillin-resistant Staphylococcus aureus: possible infection control implications. Infect Control Hosp Epidemiol. 1997; 18: 622-627.

11. Kalenić S, Budimir A, Bošnjak Z, et al. Smjernice za higijenu ruku u zdravstvenim ustanovama. Liječ Vjesn. 2011; 133: $155-170$.

12. Chan HT, White P, Sheorey H, Cocks J,.Waters MJ. Evaluation of the biological efficacy of hydrogen peroxide vapour decontamination in wards of an Australian hospital. J Hosp Infect. 2011; 79: 125-128.

13. Herruzo R, Vizcaíno MJ, Herruzo I. Quantifying Glossair ${ }^{\mathrm{TM}} 400$ efficacy for surface disinfection of American Type Culture Collection strains and micro-organisms recently isolated from intensive care unit patients. J Hosp Infect. 2014; 87: 175-178.

14. Passaretti CL, Otter JA, Reich NG, et al. An evaluation of environmental decontamination with hydrogen peroxide vapor for reducing the risk of patient acquisition of multidrug-resistant organisms. Clin Infect Dis. 2013; 56(1): 27-35.

15. Koburger T, Below H, Dornquast T et al. Decontamination of room air and adjoining wall surfaces by nebulizing hydrogen peroxide. GMS Krankenhaushygiene Interdisziplinär. 2011; 6(1): 1-10.

16. French GL, Otter JA, Shannon KP et al. Tackling contamination of the hospital environment by methicillin-resistant Staphylococcus aureus (MRSA): a comparison between conventional teminal cleaning and hydrogen peroxide vapour decontamination. J Hosp Infect. 2004; 57: 31-37.

17. ASP Glosair ${ }^{T M} 400$ cartridge, Johnson\&Johnson, Inc. 2010.

18. Roques C. Improvement of vancomycin-resistant enterococci eradication in hospitals by combined barrier precautions and disinfection using an automatic dry mist system. Eur Infect Dis. 2010; 4(1): 63-65.

19. ASP Glosair ${ }^{T M} 400$ User Manual, Johnson\&Johnson company. 2010. 


\section{DECONTAMINATION OF SURFACES IN THE HOSPITAL ENVIRONMENT WITH HYDROGEN PEROXIDE - OUR EXPERIENCE IN UNIVERSITY HOSPITAL DUBRAVA}

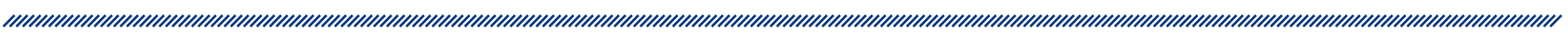

1 Dubravka Grgurić

1 Valentina Košćak

1 University Hospital Dubrava, Zagreb

\section{Abstract

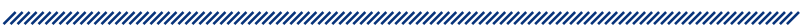

The ability of bacteria to survive on different surfaces in the hospital environment is an important factor in their transfer from a patient or healthcare worker to the environment, another person or patient. Due to the above reasons, cleaning and disinfection of the environment are very important since the contaminated environment can serve as a reservoir for potential pathogens. Disinfection can be performed mechanically (manual) or with a machine. KB Dubrava owns a decontamination device, GlosairTM 400, which disperses hydrogen peroxide in environment and decontaminates environment and surfaces at a certain time. Room decontamination is performed after interruption of isolation measures in patient room ie after discharge of a patient in which a multipurpose microorganism was found. Also, according to the indication, the decontamination of the operating room and the environment, in the patient room after the implementation of the protective isolation, and the implementation of anti-epidemic measures in the case of an emergency of hospital epidemics. During the active disinfection phase, the machine releases hydrogen peroxide, and creates a mist in the environment that disinfects all equipment and space.
One decontamination cycle lasts for three hours. After disinfection, the area is safe for new patients and staff. The advantages of decontamination of the surface area in the hospital with a dispensing device with hydrogen peroxide are the non-repair of medical supplies and equipment, it leaves no residues, so it can disinfect highly sophisticated equipment. The conducted hydrogen peroxide efficiency control on the surface shows great efficiency. All surfaces are sterile as compared to analyzed surface wiping findings after mechanical cleaning where sporadically fewer pathogens lag behind. Implementation of the room decontamination process proved to be effective in the control and prevention of hospital infections.

Keywords: disinfection, pathogen, hospital environment 